\title{
Analgesic and Anti-inflammatory Activities of the Stem Bark of Yellow Flamboyant (Peltophorum pterocarpum)
}

\section{*11OGBEIDE, OK; ${ }^{1}$ OGBONNAYA, CJ; ${ }^{1}$ ASAKITIKPI, E; ${ }^{1}$ UYI, DO; ${ }^{1}$ ALUGE, BO; ${ }^{1}$ NOSAKHARE, O; ${ }^{1}$ OTAHAGWA, WO; ${ }^{1}$ EHIGIE, CA; ${ }^{1}$ OMORUYI, U; ${ }^{2}$ AIFUWA, OS; ${ }^{3}$ GABRIEL, BO}

\author{
${ }^{*}$ Department of Chemistry, ${ }^{2}$ Department of Plant Biology and Biotechnology, ${ }^{3}$ Department of Pharmacology and Toxicology, University of \\ Benin, Benin City, Edo State, Nigeria. \\ *Corresponding Author Email: kennedy.ogbeide@uniben.edu; Tel.: +2348055949282
}

\begin{abstract}
Peltophorum pterocarpum (family; Fabaceae) is an evergreen perennial crop grown in tropical gardens. Different parts of this tree are being used for the management of many diseases. This study investigated the acute toxicity, analgesic and anti-inflammatory potentials of n-hexane extract of P. pterocarpum stem bark. Acute oral toxicity of n-hexane extract of $P$. pterocarpum stem bark was investigated using standard method. Analgesic activity was investigated by using acetic acid-induced writhing model, using indomethacin as a reference drug. Antiinflammatory activity of n-hexane extract of $P$. pterocarpum stem bark was investigated by using formalin-induced paw licking model, using aspirin as standard drug. In the acute toxicity study, mortality was observed at 500 and $2500 \mathrm{mg} / \mathrm{kg}$ body weight. In the acetic acid induced writhing test, the n-hexane extract of $P$. pterocarpum (100 and $200 \mathrm{mg} / \mathrm{kg}$ body weight) showed a significant reduction in the number of writhing with $55.5 \%$ and $60 \%$ of inhibition respectively. In formalin-induced rat paw oedema test for acute inflammation, the n-hexane extract of $P$. pterocarpum in 50, 100 and $200 \mathrm{mg} / \mathrm{kg}$ body weight showed $26.00 \%, 27.89 \%$ and $32.27 \%$ inhibition of oedema respectively after 4hours, which is comparable to that of standard drug-aspirin $(33.59 \%)$. These results validated that the extract of $P$. pterocarpum possesses significant analgesic and anti-inflammatory properties.
\end{abstract}

DOI:https://dx.doi.org/10.4314/jasem.v23i7.19

Copyright: Copyright (C) 2019 Ogbeide et al. This is an open access article distributed under the Creative Commons Attribution License (CCL), which permits unrestricted use, distribution, and reproduction in any medium, provided the original work is properly cited.

Dates: Received: 08 May 2019; Revised: 15 June 2019; Accepted 20 July 2019

Keywords: Peltophorum pterocarpum, acute toxicity, analgesic activity, anti-inflammatory activity

Free radicals are chemical species with one or more unpaired electrons such as superoxide anion $\left(\mathrm{O}_{2}^{-}\right)$and hydroxyl radical $\left(\mathrm{OH}^{-}\right)$(Dennis, 2010). Free radicals are generated as byproducts of normal aerobic metabolism and also from reactions with xenobiotics (Singh-Deveraj and Jialal, 2005). They may either donate an electron to or accept an electron from other molecules and hence can behave as oxidizing agents or reducing agents (Cheeseman, 1993). Organic free radicals cause destructiveness by peroxidation of cellular components while inorganic free radical is an important class of free radicals such as hydrogen peroxide and superoxide anion $\left(\mathrm{O}_{2}^{-}\right)$(Gupta, 2016). Oxidative damage to DNA, proteins and other macromolecules has been implicated in the pathogenesis of a wide variety of diseases including diabetes, cardio vascular disease, cancer, Alzheimer's disease, inflammatory diseases, ageing and so on (Halliwell, 1994). Secondary metabolites are the classes of compounds which are known to display therapeutic activities against several sicknesses in man, therefore explain the use of traditional therapeutic plants for the treatment of some diseases (Sabri et al., 2012). Unlike primary metabolites, the absence of secondary metabolites does not result in instant death, but rather in the long-term weakening of the organism's survivability, fertility, or aesthetics, or perhaps in no significant change at all. According to (Li et al., 2006), phenolic compounds is one of the greatest abundant groups of constituents in plant kingdom ranging from simple molecules such as phenolic acids to complex composites such as tannins.

Proximate analysis helps to set up a definite standard for dried crude drugs in order to avoid batch-to-batch dissimilarity and also to judge their quality (Backer and Hyne, 2012). Ash is categorized as physiological ash which results from the plant tissue itself and nonphysiological ash which is the remains after ignition of extraneous matter (example sand and soil) (Khandelwa, 1998). The total ash comprises carbonates, phosphates, silicates and silica. Acidinsoluble ash measures the occurrence of silica mainly sand and siliceous earth. Water soluble ash is the 
difference in weight between the total ash and the residue obtained after boiling the total ash in water (Backer and Hyne, 2012). Extractive values determine the quantity of active constituent extracted with dissimilar solvents in a given quantity of plant drug and use of a single solvent is the means of providing information on the value of a particular drug sample (Backer and Hyne, 2012).

Toxicology is the study of the antithetical effects of chemical, biological or physical agents on existing organisms (Radenkova-Saeva, 2008). Therapeutic plants behave as authentic because of bioactive chemical composites and the point that they are of natural source, however, does not show that they are harmless. Acute toxicity refers to the adverse effects of a substance or from frequent contacts in a short period of time (usually 24 hours) while chronic toxicity denotes the adverse health effects from repeated exposures, often at lower levels to a substance over a longer period (months or years) (International, 2008). It is normally considered dishonourable to use humans as a test subject for acute (or chronic) toxicity research (Walum, 1998).

Pain according to International Association for the Study of Pain (IASP) is unpleasant, sensory and sensitive involvement associated with actual or potential tissue destruction or described in terms of such destruction (Hassan et al., 2015). Pain is categorized into acute pain which is the body's warning of the current damage to tissue or disease and chronic pain which is pain that lasts much longer than pain normally would, with a particular injury (Manish et al., 2010). Analgesics are the painkiller substances which act by the absence of pain without losing awareness (Manish et al., 2010). Sources of analgesic drugs are divided into synthetic drugs such as paracetamol, ibuprofen and diclofenac and natural drugs obtained from plants, animals or microbes (Agli et al., 2013).

Inflammation is a portion of the complex biological reaction of body tissues to dangerous stimuli such as pathogens, impaired cells, or irritants and is a defensive response involving immune cells, blood vessels, and molecular mediators. Five conventional signs of inflammation are heat, pain, redness, swelling and loss of function (Ferrero et al., 2007). Acute inflammation is the initial reaction of the body to harmful stimuli and is achieved by increased movement of plasma and leukocytes (especially granulocytes) from the blood into the hurt tissues while chronic inflammation is a prolonged inflammation that leads to progressive shift in the type of cell present at the site of inflammation such as mononuclear cells and is characterized by concurrent destruction and curing of the tissue from the inflammatory process (Ferrero et al., 2007).Foods that fight inflammation include tomatoes, olive oil, green leafy vegetables, nuts, fatty fish and fruits (Harvard, 2012). Nonsteroidal anti-inflammatory drugs are generally used to treat inflammation but these drugs are associated with harmful side effects such as gastric erosion, irritation, ulceration, bleeding, etc (Agli et al., 2013).

Peltophorum pterocarpum belongs to the family of Fabaceae. It is natural to tropical Southeastern Asia and a prevalently ornamental tree grown around the world (Shyamal et al., 2014). Different parts of this tree are used to treat numerous illnesses such as stomatitis, skin troubles, constipation, ringworm and its flower extract is known to be a good sleep inducer and used as cure for insomnia (Burkill, 1995). Previous investigations revealed the presence of secondary metabolites such as alkaloids, flavonoids, saponins, sterols, terpenoids, tannin and coumarins in petroleum ether and toluene extracts of the $P$. pterocarpum. Methanol and ethyl acetate extracts of the flowers have been reported for their analgesic activity. However, to the best of our knowledge, this is the first report of the analgesic and antiinflammatory activities of $\mathrm{n}$-hexane extract of $P$. pterocarpum stem bark. Consequently, the present study was designed to scientifically investigate the acute toxicity, analgesic and anti-inflammatory potentials of n-hexane extract of $P$. pterocarpum stem bark.

\section{MATERIALS AND METHODS}

Reagents and Chemicals: Acetic acid, hydrochloric acid, chloroform, n-hexane, aspirin, indomethacin and other chemicals and reagents used were of analytical grade.

Plant materials and Extraction: The stem bark of $P$. pterocarpum was collected from Ugbowo Campus of University of Benin, Benin City, Edo State, Nigeria. The plant material was identified and authenticated by Dr Akinnibosun of the Department of Plant Biology and Biotechnology, University of Benin, Benin City, where a voucher specimen number; $\mathrm{UBH}_{\mathrm{D}} 432$ was deposited. The stem bark was rinsed with water and air-dried. The stem bark was ground to powder by means of mechanical grinder. The powdered stem bark $(500 \mathrm{~g})$ was extracted with $1.3 \mathrm{~L}$ of $\mathrm{n}$-hexane by cold maceration, at room temperature for 72 hours. The extract was concentrated in-vacuo to obtain n-hexane extract with $0.38 \% \mathrm{w} / \mathrm{w}$ yield. 
Animals: Healthy Swiss mice $(26.87 \pm 4.52 \mathrm{~g})$ and healthy Wistar rats $(136.50 \pm 16.19 \mathrm{~g})$ of both sexes bred under standard conditions at the animal house; Department of Animal and Environmental Biology, University of Benin, Benin City, Nigeria. They were fed on a standard pellet diet (Bendel Feeds, Nigeria) and water was given ad libitum. All animal experiment conformed to the Guide for the Care and Use of Laboratory Animals published by National Academic Press (Committee for the Update of the Guide for the Care and Use of Laboratory Animals, 2011).

Determination of moisture content (Anonymous, 1986): Crucibles were washed and dried in an oven at $105^{\circ} \mathrm{C}$ for twenty minutes. They were thereafter cooled in desiccators for ten minutes. The crude drug ( $10 \mathrm{~g}$ ) was weighed and was dried at $105^{\circ} \mathrm{C}$ in the oven for 5 hours. The dish was transferred to the desiccators to cool, and weighed. The drying and weighing at onehour interval was continued until a constant weight was reached.

$\% \mathrm{MC}=\frac{\text { weight of moisture }(\mathrm{g})}{\text { weight of sample }(\mathrm{g})} \times 100$

Where $\mathrm{MC}=$ moisture content

Total ash: The powdered plant material (5 g) was weighed into previously ignited and dried crucibles. The material was spread in an even layer in the crucibles and ignited in a muffle furnace by gradually increasing the temperature to $600^{\circ} \mathrm{C}$ until it became ash (6 hours). The crucibles were cooled in desiccators and weighed. The total ash was calculated as the percentage of ash with reference to the powdered plant material (Backer and Heyne, 2012).

$\%$ total ash $=\frac{W_{1}-X}{N} \times 100$

Where $\mathrm{W}_{1}=$ weight of crucible + ash; $\mathrm{X}=$ weight of empty crucible; $\mathrm{N}=$ weight of initial sample used

Acid-insoluble ash: Dilute hydrochloric acid (25 mL) was added to the crucible containing the total ash and covered with a watch glass. It was boiled gently for 5 minutes. The watch glass was rinsed with $5 \mathrm{~mL}$ of hot water and the liquid was added to the crucible. The insoluble matter was collected on an ashless filter paper and washed with hot water. The filter paper containing the insoluble matter was transferred to the crucible, dried on a hot plate and ignited to a constant weight. The content of acid-insoluble ash was calculated as a percentage of ash with reference to the powdered plant material.

$\%$ Acid - insoluble ash $=\frac{\mathrm{w}_{2}}{N} \times 100$
$\mathrm{W}_{2}=$ weight of Residue

Water-soluble ash: The total ash obtained was boiled for 5 minutes with $25 \mathrm{~mL}$ of water. The insoluble matter was collected on an ashless filter paper. It was washed with hot water and ignited for 15 minutes at a temperature not exceeding $450{ }^{\circ} \mathrm{C}$. The total weight of insoluble matter was subtracted from the weight of the ash. This difference in weights represented the watersoluble ash. The percentage of water-soluble ash was calculated with reference to the powdered sample.

$\%$ Water Soluble Ash $=\frac{\mathrm{W}_{2}}{N} \times 100$

Alcohol-soluble extractive value (Khandelwal, 1998; Anonymous, 1986) (ASEV) : The air-dried plant material (5 g) was coarsely powdered and macerated with $100 \mathrm{~mL}$ of methanol for 24 hours, with frequent stirring for the first six hours and allowed to stand for the next 18 hours. The extract was filtered rapidly taking precautions against loss of solvent. $25 \mathrm{~mL}$ of the filtrate was evaporated to dryness in a tarred flat bottom shallow dish and dried at $105^{\circ} \mathrm{C}$ to constant weight. The weight was recorded. The percentage of alcohol-soluble extractive value was calculated with reference to the powdered sample.

$\% \operatorname{ASEV}=\frac{\mathrm{W}_{3}-X}{N} \times 100$

$\mathrm{W}_{3}=$ weight of crucible + filtrate

Water-soluble extractive value (WSEV): The powdered plant material was macerated with $100 \mathrm{~mL}$ of distilled water in a closed flask for 24 hours, shaking frequently for the first six hours and allowed to stand for the next 18 hours. The extract was filtered and then, $25 \mathrm{~mL}$ of this filtrate was evaporated to dryness in a tarred flat bottom shallow dish and dried at $105^{\circ} \mathrm{C}$ to constant weight and weighed. The percentage of water-soluble extractive was calculated with reference to the powdered sample.

$\% \mathrm{WSEV}=\frac{\mathrm{W}_{4}-X}{N} \times 100$

$\mathrm{W}_{4}=$ weight of crucible + Evaporated Filtrate

Acute toxicity: The acute toxicity test of the n-hexane extract of $P$. pterocarpum stem bark was carried out by the method described by (Lorke, 1983) with many modifications. The n-hexane extract $(5,50,500$ and $2500 \mathrm{mg} / \mathrm{kg}$ body weight) of the plant was solubilized in $0.1 \mathrm{~mL}$ Tween 80 . The extract was agitated vigorously prior to withdrawal of injection doses to ensure even distribution of the extract. The extracts were administered intraperitoneally to the test group whereas control received only the vehicle ( $1 \%$ Tween 80). Treated mice were observed for biological 
reactivity continuously for the first 4 hours and a number of survivors were noted after 24 hours of dosing. Animals were further observed for 14 days for any prolonged toxicity. The $\mathrm{LD}_{50}$ was calculated by using the formula:

$$
\mathrm{LD}_{50}=(\mathrm{HNLD} \times \mathrm{LLD})^{1 / 2}
$$

Where HNLD = highest non-lethal dose; LLD = lowest lethal dose

Acetic acid-induced Writhing test: The peripheral analgesic activity of hexane extract of stem bark of $P$. pterocarpum was determined by the acetic acidinduced writhing inhibition method (Whittle, 1964) with little modification. The prescreened Swiss mice employed for the experiment were divided into five groups. The extracts were administered orally at 50 , 100 and $200 \mathrm{mg} / \mathrm{kg}$ body weight. Inhibition of writhing in mice by the plant extract was compared with the inhibition of writhing by a standard analgesic; indomethacin, given orally at a dose of $20 \mathrm{mg} / \mathrm{kg}$. Acetic acid $(0.7 \%)$ at a dose of $0.1 \mathrm{~mL} / 10 \mathrm{~g}$ was administered intraperitoneally (i. p.) to create pain sensation. The number of writhes was calculated for 5 minutes immediately after the acetic acid injection. The percentage of pain protection was calculated. The percentage protection of writhing by both test and the standard drug was calculated according to the following equation:

Percentage protection $=100-\frac{X_{t}}{X_{c}} \times 100$

Where, $X_{t}=$ Average number of writhes in the treated group, $X_{c}=$ Average number of writhes in the control group.

Formalin-induced rat hind paw oedema test: The effect of n-hexane extract of $P$. pterocarpum stem bark on formalin-induced inflammation in rat paw was investigated by following the method described by (Winter et al., 1962) with minor modifications. Rats were randomly divided into five groups, each consisting of five animals. Group I serving as a negative control was given only distilled water. Group II, III and IV were given 50, 100 and $200 \mathrm{mg} / \mathrm{kg}$ of the plant extract respectively and Group V, which served as a positive control was given the standard drug, aspirin (100 mg/kg.). The animals were fasted 12 hours prior to the experiment. All drugs were administered orally. Thirty (30) minutes after oral administration of the test materials, $0.1 \mathrm{~mL} 1 \%$ formalin suspension was injected subcutaneously in the left hind paw of each animal, leading to the formation of oedema (localized inflammation) in situ.
The volume of paw oedema was measured hourly for four hours using a vernier calliper after administration of formalin. The average percent increase in paw volume with time was calculated and compared against the control group. Percent inhibition was calculated using the formula:

$\%$ Inhibition of paw edema $=1-\frac{V_{t}}{V_{c}} \times 100$

Where $V_{c}$ and $V_{t}$ represent average paw volume of control and treated animal respectively.

Statistical analysis: Data represent mean \pm SEM and $n$ $=5$ for animals in the group. They were analysed with one-way analysis of variance (ANOVA), followed by Bonferroni t-test or student-Newman-Keuls posthoc tests. $\mathrm{P}<0.05$ was considered significant.

\section{RESULTS AND DISCUSSION}

Proximate analysis is the determination of a group of closely associated constituents together (Leslie and Harry, 2017). Proximate analysis helps to set up a definite standard for dried crude drugs in order to avoid batch-to-batch difference and also to judge their value (Backer and Hyne, 2012). In the present study, result of proximate composition includes moisture content $(14.53 \pm 0.09 \%)$, total ash $(7.50 \pm 0.10 \%)$, acid insoluble ash $(1.10 \pm 0.01 \%)$, water soluble ash $(2.00 \pm 0.01 \%)$, alcohol soluble extractive value $(28.50 \pm 0.50 \%)$ and water-soluble extractive value $(27.00 \pm 0.50 \%)$ (Table1). The moisture content $(14.53 \pm 0.09 \%)$ of $P$. pterocarpum recorded in the present study was higher than $(2.3 \pm 0.6 \%)$ reported for the seed of P. pterocarpum (Anonymous, 2017) revealing that the stem bark of $P$. pterocarpum is more susceptible to microbial deterioration than the seed of the plant. The reason for low moisture content of the seed could be due to the oil contained in it, which may act as water repellant. The high total ash is a reflection of mineral content conserved in the stem bark (Chinyere et al., 2014). An ash value determination offers the basis for judging the identity and purity of any drug and provides information related to its adulteration with in-organic matters (Falodun et al., 2013). The total ash of $P$. pterocarpum recorded in the current study was in line with $7.87 \%$ reported by (Backer and Hyne, 2012). The high total ash of stem bark of $P$. pterocarpum recorded in the present study was greater than $(2.1 \pm 0.7 \%)$ reported by (Adewale $e t$ al., 2010) on the seed of P. pterocarpum. It shows that stem bark of the plant has higher mineral content than the seed. Anonymous, 2017 reported total ash of leaves of $P$. pterocarpumas $6.53 \%$ indicating that the stem bark of $P$. pterocarpum has higher mineral content than the leaves. The total ash content was 
lesser than the range of 17.44 to $33.60 \%$ for mushroom species (Egwim et al., 2011) and higher than the range of $0.38-1.9 \%$ for certain vegetables grown in Peshawar (Bangash et al., 2011). The acid insoluble ash $(1.10 \pm 0.01 \%)$ of stem bark of $P$. pterocarpumrecorded in the present study was in line with $1.25 \%$ reported by (Backer and Hyne, 2012). The determination measures the occurrence of silica mainly sand and siliceous earth. The water-soluble ash $(2.00 \pm 0.01 \%)$ of $P$. pterocarpum obtained in the present study was in line with $2.2 \%$ recorded in the previous work (Backer and Hyne, 2012). The watersoluble ash was high, showing slight or no adulteration with metal ion (Falodun et al., 2013). The alcohol soluble extractive value $(28.50 \pm 0.50 \%)$ of $P$. pterocarpum obtained in this study is similar to the result (30\%) obtained by Backer and Hyne, 2012. It determines the number of active components extracted with alcohol from a given amount of plant drug. Alcohol is a better solvent for extraction of phytoconstituents from the stem bark of $P$. pterocarpum because more phytoconstituents were extracted in it. The water-soluble extractive value $(27.00 \pm 0.50 \%)$ of $P$. pterocarpum recorded in the present study is also similar to the result (28\%) obtained by Backer and Hyne, 2012. It determines the number of active components extracted with aqueous solvent from a given quantity of plant drug (Table 1).

Table 1: Study of different parameters obtained from the analysis of powder of stem bark of $P$. pterocarpum

\begin{tabular}{cll}
\hline S/N & Determination & Percentage w/w \\
\hline 1. & Moisture content & $14.53 \pm 0.09$ \\
2. & Total ash & $7.50 \pm 0.10$ \\
3. & Acid-insoluble ash & $1.10 \pm 0.01$ \\
4. & Water soluble ash & $2.00 \pm 0.01$ \\
5. & Alcohol soluble extractive value & $28.50 \pm 0.50$ \\
6. & Water-soluble extractive value & $27.00 \pm 0.50$ \\
\hline
\end{tabular}

Values are a mean \pm standard deviation

The result for the acute toxicity in which the $\mathrm{LD}_{50}$ obtained was $158.11 \mathrm{mg} / \mathrm{kg}$ was in line with existing literature by (Syed et al., 2012) who documented an $\mathrm{LD}_{50}$ value of $122.47 \mathrm{mg} / \mathrm{kg}$ for the leaves of the plant. In inspecting drugs, determination of $\mathrm{LD}_{50}$ is one of the first stages in evaluating the lethal nature of a material (Ogbeide et al., 2018; Ogu et al., 2012). In this study, there was no indication of toxicity and variation in behavioural pattern observed in the experimental animals treated with the extract for doses $5 \mathrm{mg} / \mathrm{kg}$ and $50 \mathrm{mg} / \mathrm{kg}$. However, at doses 500 and $2500 \mathrm{mg} / \mathrm{kg}$, there were observable signs of toxicity such as restlessness, refusal of feed, seizures and death. According to Hodge and Sterner scale which proposes that, a test drug administered orally is considered extremely toxic at $\leq 1 \mathrm{mg} / \mathrm{kg}$, highly toxic at $1-50 \mathrm{mg} / \mathrm{kg}$, moderately toxic at $50-500 \mathrm{mg} / \mathrm{kg}$, slightly toxic at $500-5000 \mathrm{mg} / \mathrm{kg}$, practically non-toxic at $5000-15,000 \mathrm{mg} / \mathrm{kg}$ and relatively harmless at $\geq 15,000 \mathrm{mg} / \mathrm{kg}$ (Ogbeide et al., 2018). Hence, from the present study, $P$. pterocarpum stem bark could be moderately toxic (Table 2).

Table 2: Acute toxicity of the n-hexane extract of $P$. pterocarpum stem bark

\begin{tabular}{llll}
\hline Groups & $\begin{array}{l}\text { Doses } \\
(\mathrm{mg} / \mathrm{kg})\end{array}$ & Mortality & $\%$ Mortality \\
\hline P.p extract & 5 & $0 / 3$ & 0 \\
P.p extract & 50 & $0 / 3$ & 0 \\
P.p extract & 500 & $1 / 3$ & 33 \\
P.p extract & $25 \mathrm{OO}$ & $2 / 3$ & 66 \\
Control (Tw) & $0.2 \mathrm{Ml}$ & $0 / 3$ & 0 \\
\hline
\end{tabular}

P.p: P. pterocarpum stem bark; Tw: Tween 80 (control); $\mathrm{LD}_{50}=$ (highest non-lethal dose $\times$ lowest lethal dose) ${ }^{1 / 2} ; \mathrm{LD}_{50}=$ $158.114 \mathrm{mg} / \mathrm{kg}$

Analgesic or pain killer is any member of the set of drugs used to attain analgesia, free from pain. Analgesic drugs act in several ways on the peripheral and central nervous systems. In the acetic acidinduced writhing, n-hexane extract of the stem bark of $P$. pterocarpum, significantly $(\mathrm{p}>0.05)$ showed a dosedependent decrease in the number of writhes within 5 minutes of injection of acetic acid $(0.7 \% \mathrm{v} / \mathrm{v})$ when related to control. The n-hexane extract of $P$. pterocarpum (100 and $200 \mathrm{mg} / \mathrm{kg})$ showed a significant reduction in a number of writhes with 55.6 and $60 \%$ of inhibition respectively (see Table 3 ). The plant extract at a dosage of $50 \mathrm{mg} / \mathrm{kg}$ showed $0 \%$ inhibition. Maximum inhibition of writhing was observed at $200 \mathrm{mg} / \mathrm{kg}$ with $60 \%$ compared with standard indomethacin $(76.5 \%)$. The extract protected the mice against chemically induced noxious stimuli (Sarvesh et al., 2017). Intra-peritoneal administered acetic acid produced high levels of prostaglandins PGE2 and PG-F $F_{2 \alpha}$ in peritoneal fluid (Sarvesh et al., 2017). The abdominal constriction in mice was related to sensitization of peritoneal nociceptors by prostaglandin (Bose et al., 2007; Sengar et al., 2015). The abdominal contraction response induced by acetic acid is a sensitive technique to establish peripherally acting painkillers (Achinta et al., 2007). The analgesic effect displayed by the extract is connected to the inhibition of prostaglandin level (Sarvesh et al., 2017) (Table 3). Inflammation induced by formalin caused the formation of rat paw oedema. In the negative control group, the size of the paw continued to rise with time until after two hours when it began to fall. This decrease in paw size of the negative control group is probably due to the action of antibodies combating inflammation in the animal. In the reference and test groups, however, there was noticeable rise in the paw size within hours, due to the action of the antioxidants existing in them (Table 4). 
Table 3: Effect of $P$. pterocarpum n-hexane extract on the acetic acid-induced peripheral pain in mice

\begin{tabular}{llll}
\hline Groups & $\begin{array}{l}\text { Dose } \\
(\mathbf{m g} / \mathbf{k g})\end{array}$ & $\begin{array}{l}\text { Mean } \pm \text { SEM } \\
\text { acetic acid }\end{array}$ & $\begin{array}{l}\text { \% } \\
\text { inhibition }\end{array}$ \\
\hline Control $(\mathrm{Dw})$ & $0.2 \mathrm{~mL}$ & $38.33 \pm 4.04$ & - \\
Indomethacin & 20 & $9.00 \pm 1.16^{* * *}$ & 76.5 \\
P.p extract & 50 & $38.33 \pm 2.33$ & 0 \\
P.p extract & 100 & $15.33 \pm 2.03^{* *}$ & 55.6 \\
P.p extract & 200 & $17.00 \pm 6.08^{* *}$ & 60
\end{tabular}

Data show the mean \pm SEM acetic acid at 5 minutes of injection of acetic acid expressed as percentage inhibition. Values with an asterisk (*) within a column are significantly different $(n=5, p>$ 0.05 , one-way analysis of variance followed by the StudentNewman-Keuls' test). Dw: Distilled water (negative control); P.p:Peltophorum pterocarpum stem bark; Indomethacin: Positive control.

Table 4: Effect of P. pterocarpum extract on rat paw oedema

\begin{tabular}{|c|c|c|c|c|c|}
\hline & \multicolumn{5}{|c|}{ Increase in rat paw volume in $\mathrm{mm}$} \\
\hline Groups & $\begin{array}{l}\text { Dose } \\
(\mathrm{mg} / \mathrm{kg})\end{array}$ & $\begin{array}{l}\text { Mean } \pm \\
\text { SEM lhr }\end{array}$ & $\begin{array}{l}\text { Mean }= \\
\text { SEM } 2 h_{r}\end{array}$ & $\begin{array}{l}\text { Mean } \pm \\
\text { SEM 3hr }\end{array}$ & $\begin{array}{l}\text { Mean } \pm \\
\text { SEM thr }\end{array}$ \\
\hline Control(Dw) & & $5.53 \pm 0.15$ & $5.77 \pm 0.15$ & $5.50 \pm 0.29$ & $5.27 \pm 0.15$ \\
\hline & 100 & $4.00=$ & $3.90=0.06$ & $3.90 \pm 0.06$ & 0.17 \\
\hline P.pes & 50 & $4.50 \pm 0.29$ & $4.10=0.06$ & $4.00 \pm 0.29$ & $3.90=0.06$ \\
\hline P.pes & 100 & $4.27 \pm 0.15$ & $4.00=0.29$ & $4.00=0.12$ & $3.80 \pm 0.12$ \\
\hline P.p extract & 200 & $4.00=0.29$ & $3.97 \pm 0.09$ & $3.97 \pm 0.09$ & $3.57 \pm 0.15$ \\
\hline
\end{tabular}

Data show the mean $\pm S E M$ rat paw volume at the different time point, $n=5, p$-value < 0.05,Dw: Distilled water (negative control); P.p:Peltophorumpterocarpum stem bark; Ref. drug: Aspirin (Positive control).

The results of the present study showed the dosagedependent activity of the plant extract in hindering inflammation with \% inhibition of 26.00 at $50 \mathrm{mg} / \mathrm{kg}$ (least dosage) and 32.27 at $200 \mathrm{mg} / \mathrm{kg}$ (highest dosage) after 4 hours. The \% inhibition of the reference drug, aspirin, was 33.59; hence the plant exhibited activity comparable to that of the standard medicine. Another study described by (Payal, 2012) of the stem bark of methanol extract, documented \% inhibition of 13.02 at $300 \mathrm{mg} / \mathrm{kg}$ after five hours. This difference in the result may be due to the use of dissimilar solvents. However, other influences that may affect the results include the season, time of harvest, age and maturity of plant, place where the sample was obtained and other environmental factors (Ogbeide et al., 2018) (Table 5).

\begin{tabular}{llllll}
\multicolumn{6}{c}{ Table 5: \% inhibition of $P$. pterocarpum stem bark } \\
\hline Group & \multicolumn{2}{c}{$\%$ inhibition } & & & \\
\cline { 2 - 6 } & $\begin{array}{l}\text { Dose } \\
(\mathrm{mg} / \mathrm{kg})\end{array}$ & $1 \mathrm{hr}$ & $2 \mathrm{hrs}$ & $3 \mathrm{hrs}$ & $4 \mathrm{hrs}$ \\
& - & - & - & - & - \\
\hline Control(Dw) & 100 & 27.67 & 32.41 & 29.09 & 33.59 \\
Ref. drug & 18.63 & 28.94 & 27.27 & 26.00 \\
P. p extract & 50 & 18.78 & 30.66 & 27.27 & 27.89 \\
P. p.extract & 100 & 22.78 & \\
P. p.extract & 200 & 27.67 & 31.20 & 27.81 & 32.27 \\
\hline
\end{tabular}

Conclusion: This study established that the n-hexane extract of stem bark of $P$. pterocarpum could be a promising source of analgesic and anti-inflammatory agent. To the best of our knowledge, this is the first report on the analgesic and anti-inflammatory activities of n-hexane extract of $P$. pterocarpum stem bark. Further phytochemical studies are ongoing in our laboratory to isolate the bioactive principles responsible for the analgesic and anti-inflammatory activities.

Acknowledgement: The Authors acknowledge the support of the Natural Products Research Group, Department of Pharmaceutical Chemistry, Faculty of Pharmacy for allowing us to use their laboratory facilities in carrying out this research.

\section{REFERENCES}

Achinta, S; Mohammad, A;Masad, S;Cobakar, J;Kundu, K;Bidyut, DK;Lufan, N;Satyajit, DS(2007). The analgesic and anti-inflammatory activities of the extract of Phyllantus reticulatus in mice model.Pharmaceutical Biology. 45(5):355359.

Adewale, A; Rotimi, AO; Rao, BVSK; Prasad, RBN (2010). Chemical component and fatty acid distribution of Delonixregia and Peltophorum pterocarpum seed oils. Food Sci. and Technol. Res. 16(10):565-570.

Agli, MD; Lorenzo, C; Badea, M (2013). Plant food supplements with anti-inflammatory properties: a systematic review. Crit. Rev. Food Sci. Nutr.53(4):403-413.

Anonymous (1986).The Ayurvedic pharmacopoeia of India.The government of India Ministry of Health and Family Welfare Department of Health.1:143.

Anonymous (2017).Proximate composition and phytochemical constituents of leaves of Peltophorum pterocarpum. Pharmacognosy J.1:150.

Backer, DC; Heyne, K(2012).Pharmacological and phytochemical investigation of Peltophorum pterocarpum. Int. J. of Ayurvedic Med.3(4):196217.

Bangash, JA; Muhammad, A;Faizullah, K; Faridullah, K; Aminu, UR; Iqbal, H (2011). Proximate composition, minerals and vitamins content of selected vegetables grown in Peshawar. $J$. Chem.Soc. Pak. 33(1):118.

Bose, AS; Mondal, JKG; Ghosh T;Dash,GK; Si, $\mathrm{S}(2007)$.Analgesic, anti-inflammatory and antipyretic activities of ethanolic extract and it 
fractions of Cleome rutidosperma.Fitoterapia. 78:515-520.

Burkill, HM(1995). The useful plants of west tropical Africa.Royal Botanic Gardens.3(2):100-143.

Cheeseman, KH; Slater, $\mathrm{TF}(1993)$.An introduction to free radical chemistry.Br Med Bull. 49:481-493.

Chinyere, VD; Rachael, UU; Okeke, CU; Chinelo, AE; Nneka, FO; Ebere, EA;Ribian OA(2014). Determination of proximate composition of various parts of two Dracaena species.Int. J. of Botany. 10 (1):37-41.

Dennis, RM (2010). Neurology secrets.Baylor College of Medicine.5(1):1-20.

Egwin, EC; Elem RC;Egwuche, RU(2011).Proximate composition, phytochemical screening and antioxidant activity of ten selected wild edible Nigerian mushroom.Ann. Rev. Eco. 1:89-94.

Falodun, A; Igbe, I; Imieje, V(2013).Phytochemical screening, proximate analysis and acute toxicity of leaves Cola lepidota, K. schum (Sterculiaceae).Recruit Scientist. 1:1684-1689.

Ferrero, ML; Nielsen, OH; Andersen PS; Girardin SE(2007). Chronic inflammation: the importanceof NOD2and NALP3 in interleukin. Clin. Exp. Immunol. 147:2.

Gupta, PK (2016). Fundamentals of toxicology.Elsevier. 1:5-50.

Halliwell, B(1994). Free radicals, anti-oxidants and human disease: curiosity, cause or consequence? Lancet.344:721-724.

Harvard, U(2012). Foods that fight inflammation.Harvard Health Publishing Harvard Medical School. 1:1-5.

Hassan, FI; Abdulkadir, UZ; Yaro, AH; DanmalamUH(2015). Analgesic, antiinflammatory, anti-pyretic activities of methanol leaf extract of DalbergiasaxatilisHook F. in rats and mice. J. Ethnopharmacol. 1:74-78.

International, C (2008). Annual meeting.Conference by continents. 19:10.

Kapoor, LD; Singh, A; Kapoor, SL; Srivastava, SN(1969).Survey of Indian medicinal plants for saponins, alkaloids and flavonoids.Lloydia. 32:297-302.
Khandelwal, KR(1998). Textbook of practical pharmacognosy.Techniques and Experiments. 2:146-160.

Leslie, HF; Harry, JF(2017).Introduction- general methods for proximate and mineral analysis.Modern Food Analysis. 1:1-2.

Li, Y; Guo, C; Yang, J; Wei J;Xu, J; Cheng S(2006). Principles of food chemistry.Food Chem. 96:254260.

Lorke, D(1983). A new approach to practical acute toxicity testing.Arch Toxicology. 54:275-287.

Manish, K; Abhilasha, S; Zafar A(2010). A review on analgesic: from natural sources. Int. J. of Pharmaceutical and Biological Archives. 1 (2):95100.

Oduro, I; Larbie, C; Amoako, TNE; Antwi-Boasiako, AF (2009). Proximate composition, and basic phytochemical assessment of two common varieties of Terminaliacatapa (Indian almond). $J$. Sci. Technol.29:1-6.

Ogbeide, OK; Dickson, VO; Jebba, RD; Owhiroro, DA;Olaoluwa, MO; Imieje, VO; Erharuyi, O; Owolabi, BJ; Fasinu, P; Falodun, A(2018). Antiplasmodial and acute toxicity studies of fractions and cassane-type diterpenoids from the stem bark of Caesalpiniapulcherrima (L.) Sw. Trop J. Nat Prod Res. 2(4):179-184.

Ogu, GI; Aisuodionoe, ME; Nwachukwu, PU(2012).Antiplasmodialactivity of Caesalpiniapulcherrima (Swarts) stem bark extract against Plasmodium berghei in albino mice. Int. J. Bio., Pharmacy and Allied Sci. 1(2):168178.

Payal, MP(2012).Pharmacognostical and phytopharmacological investigation of Peltophorumpterocarpum (DC) Backer ex. Heyne.Int. J. of Ayurvedic Medicine. 3(4):196-217.

Radenkova, SJ(2008). Historical development of toxicity.ActaMedicaBulgarica. $35: 1$

Sabri, FZ; Belarbi M; Sabri, S; Alsayadi, MMS(2012).Screening and identification of some compounds from mallow. Scholar Research Library Phytochemical. 2(4):512-516. 
Salehi-Surmaghi, MH; Aynehchi, Y; Amin, GH;Mahhmoodi, Z(1992).Survey of Iranian plants for saponins, alkaloids, flavonoids and tannins.Int. J. of Pharmacognosy, 2(4):17-30.

Sarvesh, KP; Bhawana, S; Samriti, F; Swapnil, S(2017).Studies on analgesic, anti-inflammatory activities of stem and roots of Inula cuspidate.J. of Traditional and Complementary Medicine. 7:532537.

Segelman, AB; Farnsworth, NR; Quimby, MD (1969). False negative saponins test results induced by the presence of tannins.Lloydia. 32:52-58.

Sengar, NA; Joshi, SK; Prasad, SH (2015).Antiinflammatory, analgesic and anti-pyretic activities of standardized root extract of Jasminumsambac.J Ethnopharmacol.160:140-148.

Shyamal, KJ; Arindam, G; Atasi, S; Dilip, G (2013). Peltophorumpterocarpum: chemical and pharmacological aspects. International Journal of Pharmaceutical and Research.48:0975-6232.

Singh-Deveraj, U; Jialal, I (2005). Vitamin E, oxidative stress and inflammation.In Annual Review of Nutrition.25:151-174. four mimosaceous plants leaves in mice. J. Pharm. 2(2):291-295.

Visweswari, G; Rita, C; Rajendra W (2017). Phytochemical screening of active secondary metabolites present in Withaniasomnifera root: role in traditional medicine. Int. J. Pharmaceu.Res. 1:0975-6232.

Walum, E(1998). Acute oral toxicity.Environ. Health Perspective. 106 (2):497-503.

Whittle, BA(1964). The use of changes in capillary permeability in mice to distinguish between narcotic and non-narcotic analgesic. $B r \quad J$. Pharmacol Chemother. 22:246-253.

Winter, CA; Risley, EA; Nuss, GW(1962). Carrageeninduced edema in hind paw of the rat as an assay for anti-inflammatory drugs. Exp. Biol. Med. 111:544-547.

Syed, MA; Salman, A; Farhana, T; Mohtasheemul HM; Iqbal; A (2012). Acute systemic toxicity of 